\title{
Corrosion and microstructural characterization of martensitic stainless steels submitted to industrial thermal processes for use in surgical tools
}

\author{
José Renato Jatobá Marcuci, Elki Cristina de Souza, Claudia Cristiane Camilo*, Pedro Luiz Di Lorenzo, \\ João Manuel Domingos de Almeida Rollo
}

\begin{abstract}
Introduction: The mechanical properties and corrosion resistance of a material are dependent on its microstructure and can be modified by phase transformation. When a phase transformation occurs in a material it usually forms at least one new phase, with physical-chemical characteristics that differ from the original phase. Moreover, most phase transformations do not occur instantly. This paper presents an evaluation of the phase transformation of martensitic stainless steels ASTM 420A and ASTM 440C when submitted to different thermal processes. Methods: Dilatometry tests were performed with several continuous heating and cooling rates in order to obtain the profiles of the continuous heating transformation (CHT) and continuous cooling transformation (CCT) diagrams for these two types of steel. Also, the temperature ranges for the formation of the different phases (ferrite and carbides; ferrite; austenite and carbides; non-homogeneous and homogeneous austenite phases) were identified. Rockwell hardness (HRC) tests were performed on all thermally treated steels. Anodic and cathodic potential dynamic polarization measurements were carried out through immersion in enzymatic detergent as an electrolyte for different samples submitted to the thermal processes in order to select the best routes for the heat treatment and to recommend steels for the manufacture of surgical tools. Results: The martensitic transformation temperature tends to increase with increasing temperature for the initiation of cooling. The $440 \mathrm{C}$ steel had a higher hardness value than the $420 \mathrm{~A}$ steel at the austenitizing temperature of $1100^{\circ} \mathrm{C}$. Above the austenitizing temperature of $1100^{\circ} \mathrm{C}$, the material does not form martensite at the cooling rate used, which explains the sharp decline in the hardness values. Conclusion: The study reported herein achieved its proposed objectives, successfully investigating the issues and indicating solutions to the industrial problems addressed, which are frequently encountered in the manufacture of surgical instruments.
\end{abstract}

Keywords Martensitic stainless steels, Industrial thermal processes, Surgical tools, Dilatometric tests, Phase transformation, Polarization curves.

\section{Introduction}

The mechanical properties and corrosion resistance of a material are dependent on its microstructure and can be modified by phase transformation (American..., 1991, 1992; Baker, 2004). When a phase transformation occurs in a material it usually forms at least one new phase, with physical-chemical characteristics that differ from the original phase. Moreover, most phase transformations do not occur instantly. Instead, they begin through the formation of numerous small particles of the new phase(s), which increase in size until the processing has been completed. The phase transformation process can be divided into two distinct stages: nucleation and growth. Nucleation involves the appearance of particles, or nuclei, with very little of the new phase (often consisting of only a few hundred atoms), which are able to grow. During the growth stage these nuclei increase in size, resulting in the consumption of portions of the original phase or all of it. The phase transformation will continue until the equilibrium condition is reached.

Pure iron exists under atmospheric pressure in two crystalline forms: a body-centered cubic form (bcc, $\alpha$-iron) that is stable at temperatures below 910 ${ }^{\circ} \mathrm{C}$ and a face-centered cubic form (fcc, $\gamma$-iron) that is stable above this temperature (American ...1992, 1999, 2002; Baker, 1992; Callister, 2007).

Since the crystalline structure of fcc is more compact than that of bcc, when the phase transformation of $\gamma$ to $\alpha$ occurs, or vice versa, there is a change in the unit cell volume which, in turn, leads to a significant change in the volume of the material. On heating there is contraction $(\alpha \rightarrow \gamma)$ and on cooling expansion $(\gamma \rightarrow \alpha)$ has been observed.

Thus, by measuring the variation in the material volume (dilatometric method), it is possible to characterize the temperatures associated with the beginning and end of the phase transformation. 
Dilatometry is widely used to determine these temperatures. It is possible to obtain a temperature curve by varying the length of the material (Garcia et al., 2002). Since the phase transformations are related to the volume variation and this, in turn, is proportional to the linear range, the points of inflection (i.e., where there is a change in the slope) on the dilatometry curve characterize the transformation temperature.

The martensite phase, which provides harder, resistant and brittle steels, is usually obtained with a rapid cooling called annealing (Baker, 1991; Garcia et al., 1992, 1996).

The atomic structure of martensite is body-centered tetragonal (bct) and is slightly less dense than the structure of austenite. Therefore, during the processing phase in the hardening process there is an increase in volume, generating a volumetric expansion of the steel with the formation of martensite. Besides these transformations, the dissolution and precipitation of carbides can also generate fields of phases in the microstructure of steel. Steels containing alloying elements, as in the case of stainless steels, can show carbide stability within certain temperature ranges. These carbides influence the properties of the steels, particularly in terms of hardness and corrosion resistance (Baker, 2004; Garcia et al., 1992, 1996).

The solubility of carbon in steel is dependent on the crystal structure. Carbon has a lower solubility in the alpha phase than in the gamma phase. Thus, there is a rejection of the alpha carbon phase, which tends to form precipitates of carbides with other steel elements. In stainless steel, for example, the element chromium may have a percentage by weight of up to $20 \%$ and, because of this, the $\alpha$ phase may be in equilibrium and precipitates of carbides of chromium may be present in the steel. In the gamma phase, carbon has a higher solubility and thus if carbides are present in the steel in the austenitic region they tend to dissolve. This dissolution is not homogeneous at first, but it becomes so at certain processing temperatures and after certain processing times (Garcia et al., 1992, 1996; Rodrigues et al., 2009).

Technique dilatometry is used to determine the phase fields that are in precipitates carbides and the temperature region in which they melt and homogenize in the material. During the heating, after the austenitizing stage is complete, there is a steady increase in the slope of the curve corresponding to the dissolution of precipitated carbides. The inflection point is characterized as the maximum point on the derived dilatometry curve, representing the final temperature of the dissolution of carbides. Subsequently, the carbides are dissolved and the austenite has a significant concentration of carbon.
With continued heating, the carbon concentration reaches equilibrium and the elements comprising the carbides are well distributed, homogenizing the austenite. This homogenization process is verified on the dilatometer curve as a decrease in the angular coefficient (slope), i.e. a reduction in the amount of the derivative. The homogenization takes place at a temperature where the slope of the dilatometric curve becomes linear (Garcia et al., 2002).

Different temperatures were used to identify the field in which the transformation of austenite with precipitates of carbides occurs, and non-homogeneous and homogeneous austenite can be determined. Martensitic stainless steels are widely used for their good mechanical properties and moderate corrosion resistance. However, the need for superior properties in specific applications has led to extensive research aimed at improving the performance of these steels (American..., 2003; Isfahany et al., 2011; Padilha et al., 2007).

\section{Methods}

Two martensitic stainless steels used to manufacture surgical supplies were studied and their chemical composition was determined according to the standard method ASTM F 899-02 (American..., 2002). Both types of stainless steel contain in their chemical composition a maximum ( $\%$ by weight) of each element as follows: manganese (Mn) $1.00 \%$; phosphorus $(\mathrm{P})$ $0.04 \%$; sulphur (S) 0.03 ; silicon $(\mathrm{Si}) 1.00 \%$. ASTM $420 \mathrm{~A}$ steel has the following elemental composition: carbon (C) $0.16-0.25 \%$; chromium (Cr) $12.00-14.00 \%$ and nickel (Ni) $1.00 \%$ while ASTM 440C steel contains C $0.95-1.20 \%$, Cr 16.00-18.00\% and Mo $0.75 \%$.

All samples were ground to 1200 mesh size and polished with chromium oxide. To visualize the microstructure of the material the chemical reagent Villela was used, which revealed the presence of the martensite phase.

The continuous heating curves were obtained using a Netzsch Dilatometer (DIL 402 C). The dilatometer consists of a resistance furnace, where the specimen is placed in contact with an alumina rod that records the variation in its length. To avoid problems associated with the oxidation of the sample, the test is performed under a continuous flow of inert gas passing through the oven. The dilatometer operates with heating rates ranging from $0.01{ }^{\circ} \mathrm{C} / \mathrm{min}$ to $50{ }^{\circ} \mathrm{C} / \mathrm{min}$ and a temperature range extending from room temperature to $1500{ }^{\circ} \mathrm{C}$.

The continuous cooling curves were obtained using a rapid quenching dilatometer, model DT1000 (ADAMEL LHOMARG), which operates with 
cooling rates of up to $500^{\circ} \mathrm{C} / \mathrm{s}$ and within a working temperature range of $160{ }^{\circ} \mathrm{C}$ to $1350^{\circ} \mathrm{C}$. In all tests samples with a cylindrical geometry were used and they were cooled by injecting Helium 5.0 (analytical) as a cooling gas.

The hardness of the materials studied was determined using the Vickers Microdurometer (Leica VNHT MOT), with a load of $1000 \mathrm{~g}$. All of the procedures were carried out according to the standard method ASTM E92-82 (American..., 2003) E2.

Electrochemical studies were carried out by monitoring the open circuit potential as a function of the immersion time, using cathodic and anodic potentio dynamic polarization curves and chronoamperometric measurements. For all electrochemical tests, samples with an exposed area of $0.8 \mathrm{~cm}^{2}$ (working electrode) were mounted in a three-electrode electrochemical cell, with a Pt plate counter-electrode and a saturated calomel reference electrode $\mathrm{Hg} / \mathrm{HgCl}_{2}$, $(\mathrm{KCl} 3.5 \mathrm{M})$. The electrochemical tests were carried out in $5 \mathrm{~mL}$ of an enzymatic detergent (Riozyme IV E Gold - Rioquímica - 356212 - Composition: Enzymes (amylase, protease, lipase and carbohydrase) solubilizing, non-ionic surfactants, solvent, colorant, fragrance and deionized water) diluted in $1000 \mathrm{~mL}$ of water as an electrolyte to simulate the hospital cleaning of surgical tools. The cathodic and anodic polarization curves were obtained at a scanning rate of $0.5 \mathrm{mV} \mathrm{s}^{-1}$ at $-300 \mathrm{mV}$ with respect to the corrosion potential $\left(\mathrm{E}_{\text {corr }}\right)$. The experiments were carried out using the Potentiostat VoltaLab with VoltaMaster 4 Analysis software.

\section{Results}

\section{Plots of CCT diagrams of steels ASTM 420A and ASTM 440C}

Based on the CHT diagrams for $420 \mathrm{~A}$ and $440 \mathrm{C}$ steels, a study was conducted to evaluate the different phase transformations with cooling at a constant rate. The thermal cycle consisted of heating at $5{ }^{\circ} \mathrm{C} / \mathrm{min}$ up to a certain pre-established temperature, soaking for 2 min and applying controlled-cooling furnace dilatometry. The heating rate of $5^{\circ} \mathrm{C} / \mathrm{min}$ is adopted in industrial furnaces. The temperatures used for the austenitizing processes were $1100{ }^{\circ} \mathrm{C}$ and $1200{ }^{\circ} \mathrm{C}$. For the 420A steel these temperatures allow cooling from the heterogeneous austenite field and from the homogeneous austenite field. For the steel $440 \mathrm{C}$ steel the temperatures allow cooling from an austenite field with the $\mathrm{M}_{7} \mathrm{C}_{3}$ and $\mathrm{M}_{23} \mathrm{C}_{6}$ carbides and from an austenite field that contains only the $\mathrm{M}_{7} \mathrm{C}_{3}$ carbide.
The cooling rates ranged from $1{ }^{\circ} \mathrm{C} / \mathrm{s}$ to $100^{\circ} \mathrm{C} / \mathrm{s}$, since these rates cover those used in industrial furnaces, that is, the range of $1{ }^{\circ} \mathrm{C} / \mathrm{s}$ to $55^{\circ} \mathrm{C} / \mathrm{s}$. Some of the curves are given in Figures 1 and 2.

The martensitic transformation temperature tends to increase with increasing temperature for the initiation of cooling.
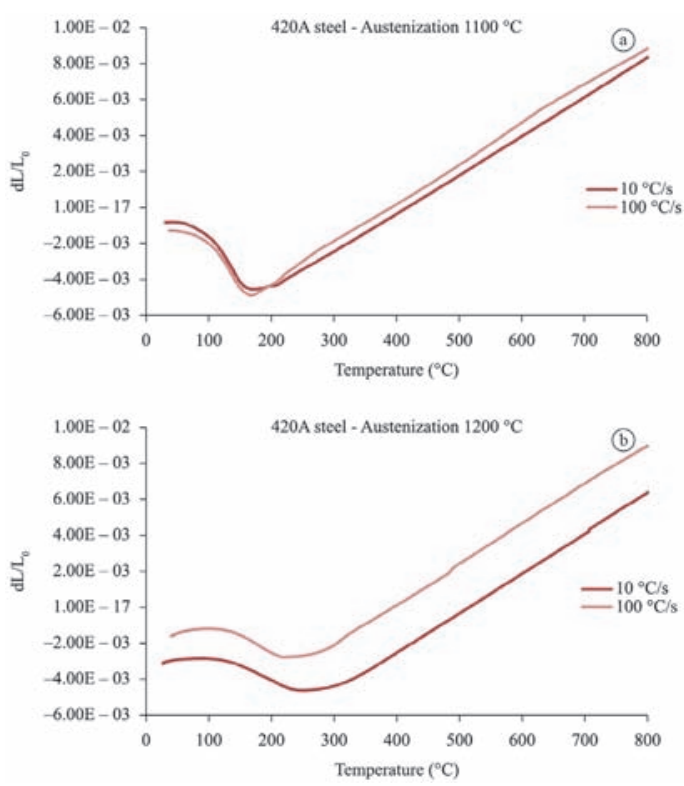

Figure 1. $d \mathrm{~L} / \mathrm{L}_{0}$ cooling curves for the martensitic stainless steel 420A. Cooling from $1100^{\circ} \mathrm{C}$ (a) and $1200^{\circ} \mathrm{C}$ (b).
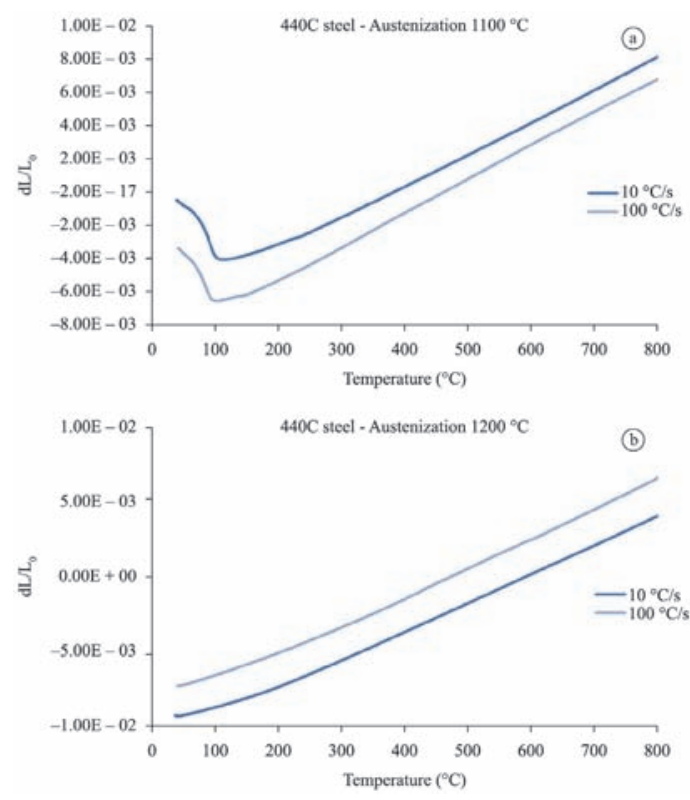

Figure 2. $\mathrm{dL} / \mathrm{L}_{0}$ cooling curves for the martensitic stainless steel 440C. Cooling from $1100{ }^{\circ} \mathrm{C}$ (a) and $1200^{\circ} \mathrm{C}$ (b). 
For the stainless steel ASTM 420A, the position of the line for Ms cooling from the heterogeneous austenite field $\left(1100{ }^{\circ} \mathrm{C}\right)$ tends to remain constant throughout the range of cooling rates imposed. In the cooling from the field of homogeneous austenite $\left(1200{ }^{\circ} \mathrm{C}\right)$, the line for Ms becomes higher as the cooling rate decreases.

When the two steels are subjected to heat treatment via the same route, the martensite is formed at lower temperatures for the 440C steel.

\section{Splitting phenomenon}

The splitting phenomenon occurs during the martensitic transformation and it is caused by the difference in the concentrations of carbon in the austenite and/ or the presence of carbides. The splitting of 420A (Figure 3a) appears when the steel is cooled in a field which is not homogeneous austenite (austenite with different concentrations of carbon). To form a smaller volume of the martensite phase in the second stage (Figure 3), the material is characterized by regions of carbon concentrations in the austenite which are higher than the average reported for other samples (Garcia et al., 1996).

On cooling from the austenite homogeneous field $\left(1200{ }^{\circ} \mathrm{C}\right)$, the splitting does not occur because when the material is at this temperature the carbon
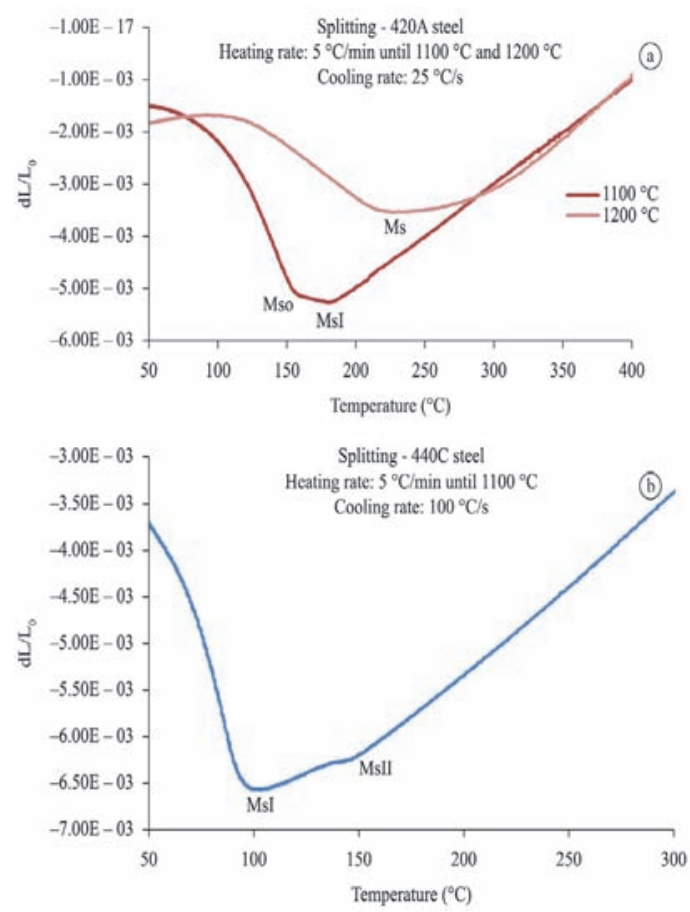

Figure 3. Occurrence of the splitting phenomenon in 420A steel (a) and $440 \mathrm{C}$ steel (b). is uniformly diffused in the austenite, resulting in a single stage martensitic transformation (Figure 3).

The presence of carbides in $440 \mathrm{C}$ steel before cooling to $1100{ }^{\circ} \mathrm{C}$ also enables the formation of splitting (Figure $3 \mathrm{~b}$ ). In this case, the stage associated with the formation of a smaller volume of martensite is the first, meaning that there are regions with lower concentrations of carbon and carbides than the average reported for the sample (Garcia et al., 1992).

\section{Hardness values for ASTM 420A and ASTM 440C steels}

The hardness values for ASTM 420A and ASTM 440C steels were obtained as a function of the austenitizing temperature (Figure 4). The heating rate, soaking time and cooling rate remained constant.

There is an austenitizing temperature that maximizes the hardness for both steels. The peak hardness of the 420A steel is reached at just above the austenitizing temperature of $1050^{\circ} \mathrm{C}$.

The 440C steel has a higher hardness value than the $420 \mathrm{~A}$ steel at the austenitizing temperature of $1100{ }^{\circ} \mathrm{C}$.

The hardness values were also obtained as a function of the cooling rate (Figures 5 and 6). In this evaluation, the heating rate, soaking time and austenitizing temperature remained constant at $1100{ }^{\circ} \mathrm{C}$ and $1200{ }^{\circ} \mathrm{C}$.

The peak hardness was similar for the two samples on cooling from $1100^{\circ} \mathrm{C}$ at a rate of $10^{\circ} \mathrm{C} / \mathrm{s}$, but the behavior of the hardness values for the two steels at other cooling rates differed (Figures 5 and 6).

Since 440C steel does not have the martensitic phase in the final structure on cooling from $1200{ }^{\circ} \mathrm{C}$,

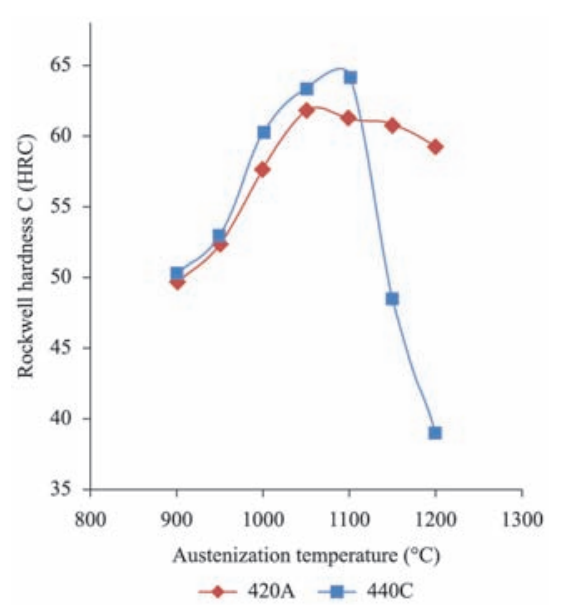

Figure 4. Hardness values for $420 \mathrm{~A}$ and $440 \mathrm{C}$ steels as a function of austenitizing temperature. Heating at $5{ }^{\circ} \mathrm{C} / \mathrm{min}$ and cooling at $25^{\circ} \mathrm{C} / \mathrm{s}$. 


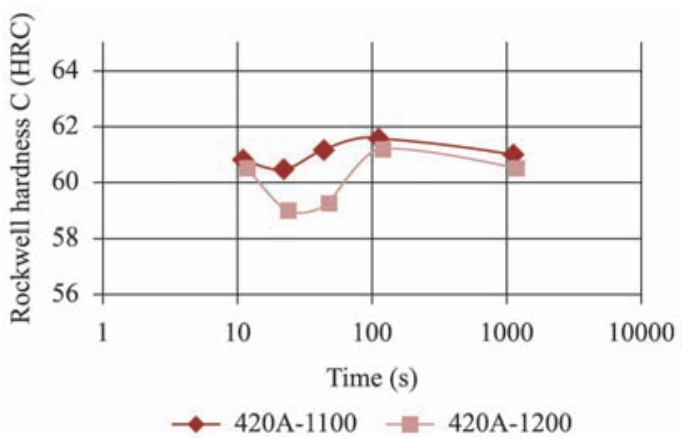

Figure 5. Hardness of 420A steel as a function of the cooling rate. Heating at $5{ }^{\circ} \mathrm{C} / \mathrm{min}$ with austenitizing temperatures of $1100{ }^{\circ} \mathrm{C}$ and $1200^{\circ} \mathrm{C}$.

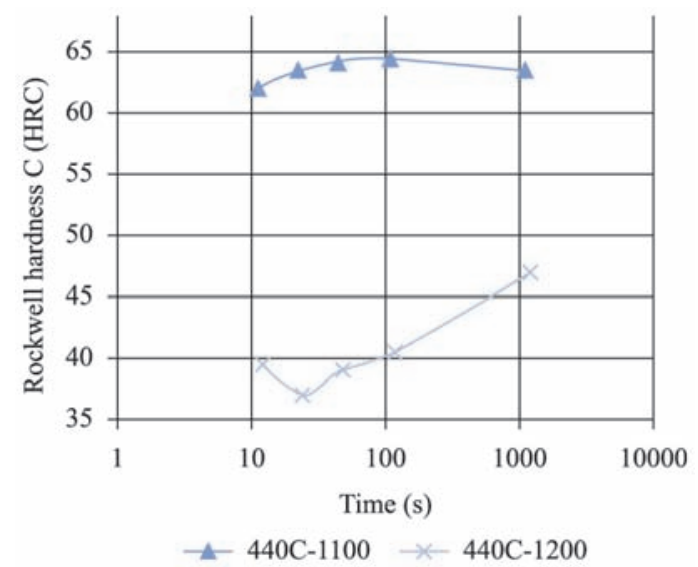

Figure 6. Hardness of $440 \mathrm{C}$ steel as a function of the cooling rate. Heating at $5{ }^{\circ} \mathrm{C} / \mathrm{min}$ with austenitizing temperatures of $1100{ }^{\circ} \mathrm{C}$ and $1200^{\circ} \mathrm{C}$.

all hardness values are much lower than those obtained with the cooling from $1100{ }^{\circ} \mathrm{C}$. Therefore, cooling from temperatures above $1100^{\circ} \mathrm{C}$ is not recommended. All of these results indicate routes which allow appropriate heat treatment to ensure high hardness values, which is an important factor for steel used to produce surgical tools.

\section{Electrochemical tests - Corrosion resistance of ASTM 420A and ASTM 440C}

To obtain results for the corrosion resistance tests which are more consistent with the practical application, an enzymatic detergent solution at room temperature was used as an electrolyte since it represents the main solution in which surgical tools are immersed for cleaning.

The anodic polarization curves shown in Figures 7 and 8 are very characteristic of stainless steels, where

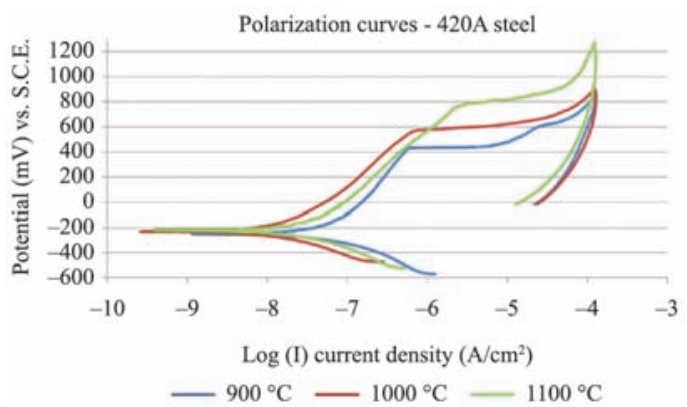

Figure 7. Anodic and cathodic potentiodynamic curves for 420A steel submitted to heat treatment beginning with austenization temperatures of $900{ }^{\circ} \mathrm{C}, 1000^{\circ} \mathrm{C}$ and $1100^{\circ} \mathrm{C}$. Potential scan rate $0.5 \mathrm{mV} \mathrm{s}^{-1}$.

the region of passivation and the pitting potential are clearly apparent. Reverse potential sweep was applied in the potentio dynamic cycles, but the repassivation processes was not observed for the two materials in the electrolyte studied.

The corrosion potential $\left(\mathrm{E}_{\mathrm{c}}\right)$, corrosion current density $\left(\mathrm{i}_{\mathrm{c}}\right)$ and pitting potential $\left(\mathrm{E}_{\mathrm{p}}\right)$ values for the two steels studied are given in Table 1 (420A) and (440C).

On increasing the austenitizing temperature a decrease in the corrosion current density and an increase in the pitting potential values occur. These results show the influence of the dissolution of carbides on the stability of the protective film, increasing the corrosion resistance.

In relation to the austenitizing temperature, the pitting potential of the 420A steel is more sensitive than that of the 440C steel, whereas for the corrosion current density, the opposite trend is observed.

In general, the $420 \mathrm{~A}$ steel is more resistant to corrosion than 440C since on applying the same conditions in the heat treatment it has lower general corrosion parameters $\left(E_{c}\right.$ and $\left.i_{c}\right)$ and the pitting potential is greater. This can be explained by the fact that $440 \mathrm{C}$ is a high-carbon steel, which promotes the formation of chromium carbides and destabilizes the passive layer of the material.

The as-received 420A steel had a corrosion potential considerably below that of the thermallytreated samples $\left(E_{c}=-324 \mathrm{mV}\right)$ and a corrosion current density above well above that of the treated samples $\left(i_{c}=123.89 \mu \mathrm{A} / \mathrm{cm}^{2}\right)$. Therefore, it is a material with a notable type of general corrosion. On the other hand, the 440C steel, as-received, showed a high general corrosion potential $\left(\mathrm{E}_{\mathrm{c}}=-157 \mathrm{mV}\right)$ and low corrosion current density $\left(i_{c}=9.40 \mu \mathrm{A} / \mathrm{cm}^{2}\right)$ for the heat-treated samples. This result coupled with the low pitting potential $\left(\mathrm{E}_{\mathrm{p}}=469 \mathrm{mV}\right)$ indicates that this material is more susceptible to pitting corrosion than 
Table 1. Corrosion potential $\left(\mathrm{E}_{\mathrm{c}}\right)$, corrosion current density $\left(\mathrm{i}_{\mathrm{c}}\right)$ and pitting potential $\left(\mathrm{E}_{\mathrm{p}}\right)$ for the as-received ASTM $420 \mathrm{~A}$ and $440 \mathrm{C}$ steels applying different temperatures in the austenitizing processes.

\begin{tabular}{ccccccc}
\hline $\begin{array}{c}\text { Heat treatment } \\
(\mathbf{Q u e n c h i n g}){ }^{\circ} \mathbf{C}\end{array}$ & \multicolumn{2}{c}{$\mathbf{E}_{\mathbf{c}}(\mathbf{m V}) \mathbf{v s .}$ S.C.E. } & \multicolumn{2}{c}{$\mathbf{i}_{\mathbf{c}}\left(\boldsymbol{\mu} \mathbf{A} / \mathbf{c m}^{2}\right)$} & \multicolumn{2}{c}{$\mathbf{E}_{\mathbf{p}}(\mathbf{m V}) \mathbf{v s . ~ S . C . E . ~}$} \\
\hline Steel & ASTM 420A & ASTM 440C & ASTM 420A & $\begin{array}{c}\text { ASTM } \\
\mathbf{4 4 0 C}\end{array}$ & $\begin{array}{c}\text { ASTM } \\
\mathbf{4 2 0}^{\mathbf{a}}\end{array}$ & ASTM 440C \\
\hline 900 & -197 & -291 & 5.36 & 90.52 & 510 & 520 \\
1000 & -218 & -287 & 3.72 & 16.42 & 605 & 590 \\
1100 & -177 & -246 & 1.82 & 5.54 & 746 & 600 \\
As received & -324 & -157 & 123.89 & 9.40 & 531 & 469 \\
\hline
\end{tabular}

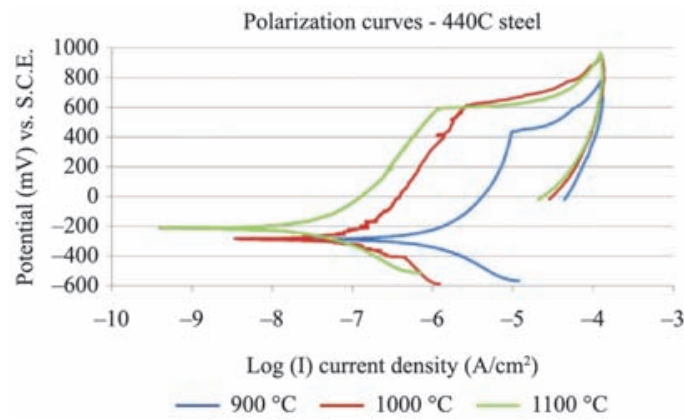

Figure 8. Anodic and cathodic potentiodynamic curves for 440C steel submitted to heat treatment beginning with austenization temperatures of $900{ }^{\circ} \mathrm{C}, 1000^{\circ} \mathrm{C}$ and $1100^{\circ} \mathrm{C}$. Potential scan rate $0.5 \mathrm{mV} \mathrm{s}^{-1}$.

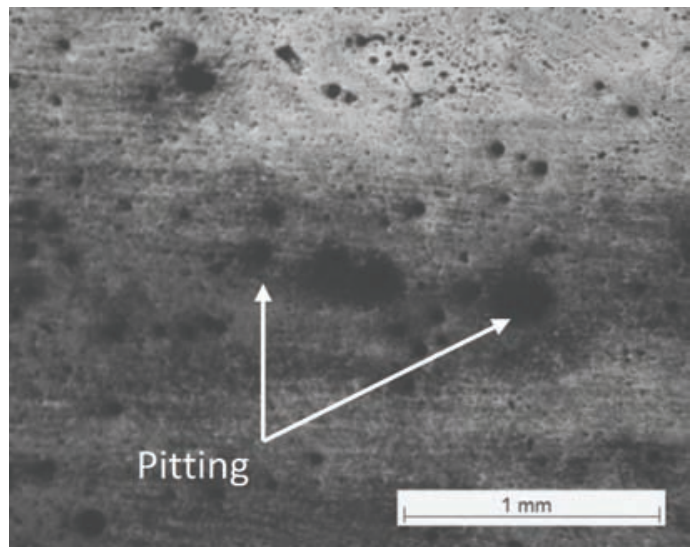

Figure 9. Micrograph of as-received 440C steel after the pitting corrosion test.

general corrosion. Figure 9 shows a micrograph of the sample of as-received steel after the pitting test.

\section{Discussion}

A comparison of the temperature-related behavior and sensitivity of the 440C and 420A steels subject to different heating rates revealed that the presence of a higher amount of carbon and chrome in the steel displaces the start and end points of the $\alpha \rightarrow \gamma$ transformation to higher temperatures and reduces the temperature range of austenite transformation.
According to Garcia et al. (1996), when the martensite phase formation occurs, it can be identified by the lowest value for the relative dilation on the dilatometric curve.

The martensitic transformation temperature tends to increase with increasing temperature at which the cooling it initiated. This can be explained by the growth of austenite grains (PAGD - prior austenite grain diameter) that hinders the transformation of more stable phases (ferrite and perlite), and facilitates the metastable transformation inherent to the martensitic structure (Garcia et al., 2002).

When the two steels are subjected to heat treatment via the same route, the martensite is formed at lower temperatures for the 440C steel because this steel has a higher proportion of carbides, which hinders the growth of the austenitic grains and consequently allows the formation of more stable phases (Garcia et al., 1992).

The splitting phenomenon occurs with the martensitic transformation and it is caused by the difference in the concentrations of carbon in the austenite and/or the presence of carbides. Its occurrence is characterized by the inflection of the $\mathrm{T} \mathrm{x} \mathrm{dL/L} \mathrm{L}_{0}$ curve inherent to martensitic transformation, which has more than one stage. When the splitting phenomenon occurs, there are two points with a minimum relative thermal expansion on the curve. The point which has the lowest numerical value is characterized as MsI and the other point is referred to as MsII when it occurs before Mso and as MsI when it occurs after Mso (Garcia et al., 1996).

The splitting of 420A occurs when the steel is cooled in a field which is not homogeneous austenite. With respect to smaller volume of the martensite phase in the second stage (Figure 3 ), the material is characterized by regions in the austenite with higher carbon concentrations compared with the average values reported for other samples (Garcia et al., 1996).

The hardness values for the ASTM 420A and ASTM 440C steels were measured as a function of the austenitizing temperature. 
There is an austenitizing temperature that maximizes the hardness for both steels. The peak hardness of the 420A steel is reached at just above the austenitizing temperature of $1050{ }^{\circ} \mathrm{C}$ and is consistent with a result reported in the literature (Garcia et al., 1992), where a steel sample with a chemical composition similar to that of $420 \mathrm{~A}$ (X45Cr13) underwent a similar assessment and presented maximum hardness at the austenitizing temperature of $1080^{\circ} \mathrm{C}$. The behavior of the curve obtained for the stainless steel 420A also exhibits a similarity with that for $\mathrm{X} 45 \mathrm{Cr} 13$, that is, with increasing austenitizing temperature there is a sharp increase in the hardness values up to the temperature associated with the maximum hardness and a slight decrease in hardness is observed after this temperature.

In this study, the 440C steel had a higher hardness value than the $420 \mathrm{~A}$ steel at the austenitizing temperature of $1100^{\circ} \mathrm{C}$. The higher amount of carbon is the most significant factor in relation to this greater hardness, as well as the presence of a higher amount of carbide, which hardens the matrix when it dissolves. Above the austenitizing temperature of $1100{ }^{\circ} \mathrm{C}$, the material does not form martensite at the cooling rate used, which explains the sharp decline in the hardness values.

The proposed methodology allowed the CCT and CHT diagrams for the martensitic stainless steels $420 \mathrm{~A}$ and $440 \mathrm{C}$ to be obtained along with an evaluation of the kinetics of the austenite transformation and the determination of the fields of the phases formed.

The investigation of the phase transformation of the martensitic stainless steels ASTM 420A and ASTM 440C, when submitted to different thermal processes, demonstrated that at different heating rates there is the presence of higher amounts of carbon and chrome, which shifts the start and end points of the $\alpha \rightarrow \gamma$ transformation to higher temperatures and reduces the temperature range of the austenite transformation and the features resulting from the heat treatments for the different fields. Also, the phases formed were efficiently analyzed through measuring the hardness and corrosion resistance.

In industrial processes, the fields of the homogeneous austenite phase are generally not used, leading to material structures (formation of carbides) that profoundly affect the corrosion resistance of the materials. Another problem, also common in industrial practices, is the loading of the kilns at high temperatures. Thus, the load is austenized at different temperatures due to the mass effect and unwanted phases may appear. The study reported herein achieved its proposed objectives, successfully investigating the issues and indicating solutions to the industrial problems addressed, which are frequently encountered in the manufacture of surgical instruments.

\section{Acknowledgements}

The authors would like to acknowledge FAPESP and CAPES Brazil for the technical and financial support given to this research.

\section{References}

American Society for Testing and Materials - ASTM. Heat treating. In: Baker H, editor. Metals handbook. 10th ed. ASM International; 1991. v. 4.

American Society for Testing and Materials - ASTM. Alloy phase diagrams. In: Baker $\mathrm{H}$, editor. Metals handbook. 10th ed. ASM International; 1992. v. 3.

American Society for Testing and Materials - ASTM. A890/ A800M: standard practice for steel casting, austenitic alloy, estimating ferrite content. Easton; 1999. Annual Book of ASTM Standards v. 1-2. p. 458-63.

American Society for Testing and Materials - ASTM. F89902: standard specification for stainless steels for surgical instruments. ASTM; 2002.

American Society for Testing and Materials - ASTM. E9282/E2: standard test method for Vickers hardness of metallic materials. ASTM; 2003.

American Society for Testing and Materials - ASTM. Metallography and microstructures. In: Baker H, editor. Metals handbook. 10th ed. ASM International; 2004. v. 9.

Callister W. Materials science and engineering: an introduction. 7th ed. John Wiley \& Sons; 2007.

Garcia AC, Cavallero FG, Capdevila C, Alvarez LF. Application of dilatometric analysis to the study of solidsolid phase transformations steels. Materials Characterization. 2002; 48(1):101-11. http://dx.doi.org/10.1016/S10445803(02)00259-0

Garcia AC, Alvarez LF, Corsi M. Effects of heat-treatment parameters on non-equilibrium transformations and properties of X45Cr13 and X60Cr14 martensitic stainless steels. Welding International. 1992; 6(8):612-21. http://dx.doi. org/10.1080/09507119209548251

Garcia AC, Jiménez JA, Alvarez LF. Splitting phenomena occurring in the martensitic transformation of $\mathrm{Cr} 13$ and CrMoV14 stainless steels in the absence of carbide precipitations. Metalurgical and Materials Transaction A. 1996; 27(7):1799-805. http://dx.doi.org/10.1007/ BF02651929

Isfahany AN, Saghafian H, Borhani G. The effect of heat treatment on mechanical properties and corrosion behavior of AISI420 martensitic stainless steel. Journal of Alloys and 
Compounds. 2011; 509(9):3931-6. http://dx.doi.org/10.1016/j. jallcom.2010.12.174

Padilha AF, Plaut RL, Rios, PR. Stainless steels heat treatment. In: Totten GE, editor. 2nd ed. Boca Raton: CRC Press; 2007. chapter 15.
Rodrigues CAD, Leiva TP, Rollo JDMA, Ekinobara F, Nunes IA. Qualidade do aço inoxidável martensítico do tipo AISI-420 utilizado na confecção de ferramentas cirúrgicas. Revista Escola de Minas. 2009; 62(4):475-80. http://dx.doi. org/10.1590/S0370-44672009000400010

\section{Authors}

José Renato Jatobá Marcuci, Claudia Cristiane Camilo*, João Manuel Domingos de Almeida Rollo

Programa de Pós-graduação Interunidades em Bioengenharia, Instituto de Química de São Carlos - IQSC, Escola de

Engenharia de São Carlos - EESC, Universidade de São Paulo - USP, Avenida Trabalhador Sancarlense, 400, Parque Arnold Schimidt, CEP 13566-590, São Carlos, SP, Brasil

Elki Cristina de Souza, Pedro Luiz Di Lourenzo

Departamento de Engenharia de Materiais, Escola de Engenharia de São Carlos, Universidade de São Paulo - USP, São Carlos, SP, Brasil 